\title{
Characterization of sputum biomarkers for asthma-COPD overlap syndrome [Erratum]
}

Gao J, Iwamoto H, Koskela J, et al. International Journal of Chronic Obstructive Pulmonary Disease. 2016;11: 2457-2465.

On page 2457, Abstract, line 3, the text "To clarify the inflammatory mediatypical for ACOS, five biomarkers, namely interleukin (IL)-13, myeloperoxidase (MPO), neutrophil gelatinase-associated lipocalin (NGAL), chitinase-like protein (YKL-40), and IL-6, were selected" should be "To clarify the inflammatory mediators typical for ACOS, five biomarkers, namely interleukin (IL)-13, myeloperoxidase (MPO), neutrophil gelatinase-associated lipocalin (NGAL), chitinase-like protein (YKL-40), and IL-6, were selected."
International Journal of COPD

\section{Publish your work in this journal}

The International Journal of COPD is an international, peer-reviewed journal of therapeutics and pharmacology focusing on concise rapid reporting of clinical studies and reviews in COPD. Special focus is given to the pathophysiological processes underlying the disease, intervention programs, patient focused education, and self management protocols.

\section{Dovepress}

This journal is indexed on PubMed Central, MedLine and CAS. The manuscript management system is completely online and includes a very quick and fair peer-review system, which is all easy to use. Visit http://www.dovepress.com/testimonials.php to read real quotes from published authors.

Submit your manuscript here: http://www.dovepress.com/international-journal-of-chronic-obstructive-pulmonary-disease-journal 